\title{
磁気挆查の土木への応用
}

\author{
池田和彦* - 松 尾正吾**. 持田豊*** \\ 土屋敦****. 長谷川淳*****
}

\section{Airborne Magnetic Survey Applied for Civil Construction Purpose}

By K. Ikeda, S. Matsuo U. Mochida, T. Tsuchiya and K. Hasegawa

\section{1. まえがき}

空中磁気探査法（航空磁気探査とも呼ばれる）は, 航 空機から，磁界它測定し，地下構造を調査する物理探査 の一方法である。

この方法は, 山岳地などの近づきにくいところでも容 易に，かつ短期間，したがって安価に地下構造を調査で きる利点のために，第二次大戦後，急速な発展を遂げ， 現在では，石油，ガス，金属鉱山などの分野において， 地質調查に前後して，かならず採用される重要な探査法 となっている。

この利点它有する空中磁気探查技術它土木工事の地質 調査に適用できるように開発し，それを青函トンネル通 過地域の地下構造調查に採用した。この結果を含めた， 2, 3 の応用例掠よび土木調查への応用上の問題点をここ に紹介する。

\section{2. 調查方 法}

地球の磁界が，北極に $\mathrm{S}$ の磁極，南極に $\mathrm{N}$ の磁極をも

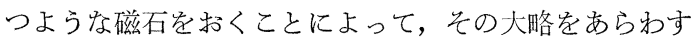
ことができることはよく知られたことであり，地球上の いかなる地点に执いても, この双極子磁界に近い標準地 球磁界名存在している。

ここで磁気探査の対象となるものは，地磁気の局地的 変化†であるが，これは比較的浅いところに分布する岩 石の磁気的性質に関連して生ずるものである。すなわ ち, この磁気的性質は, その岩石のもつ带磁率（磁化さ

\footnotetext{
* 鉄道技術研究所

** 日本鉄道建設公団青函建設局

**** 日本鉄道建設公団設計室

*****日本鉄道建設公団大阪支社

****** 住鉱コンサルタント株式会社

†地磁気の分布に打ける局地的变化を以下“磁気異 常”あるいは“異常”と呼えでいく。
}

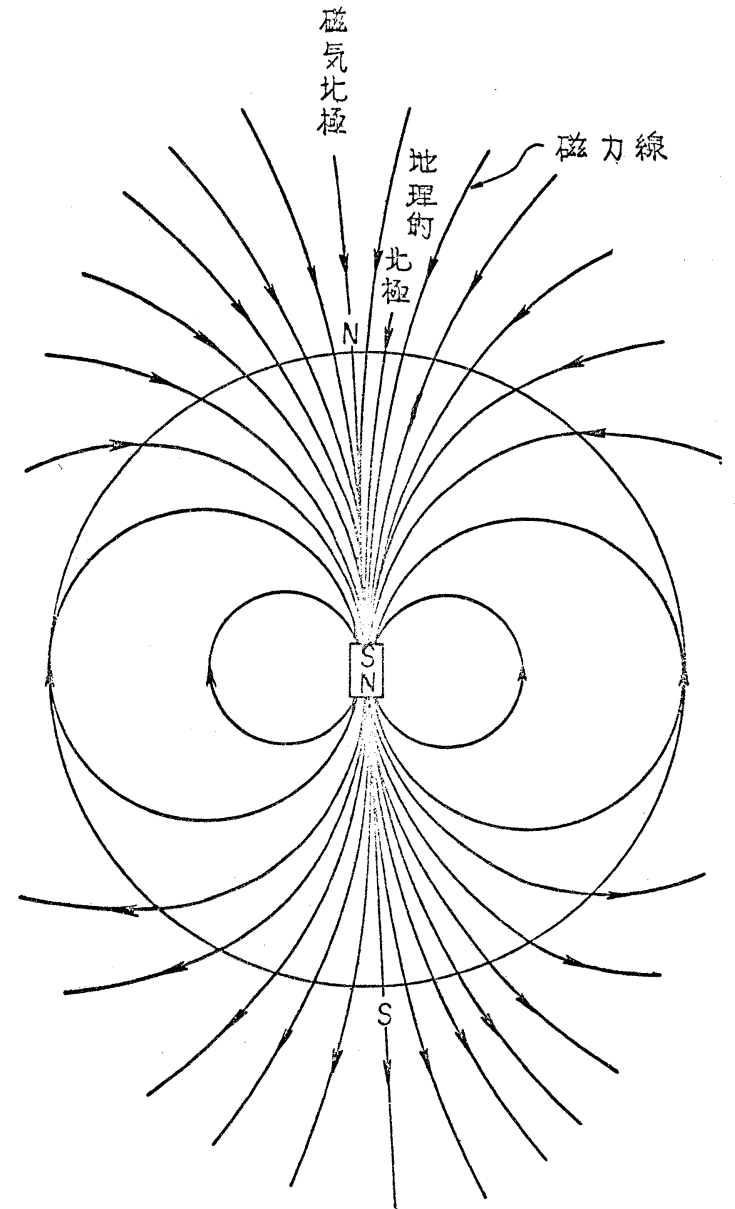

図 1 地球双極子

標準地球磁界ほ地球双極子によって生ずる磁力 線密度分布によって近似的にあらわすことがで きる。

れやすさ）と残留磁気である。岩石は，多かれ少なかれ 磁鉄鉱, 磁硫鉄鉱等の磁性鉱物をその構成鉱物として含 


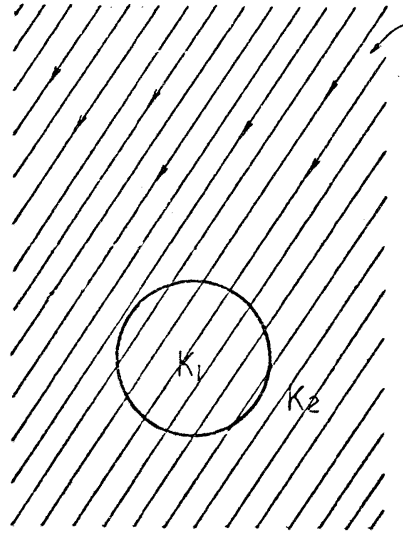

周团と带磁率加等しい

$$
\left(K_{1}=K_{2}\right)
$$

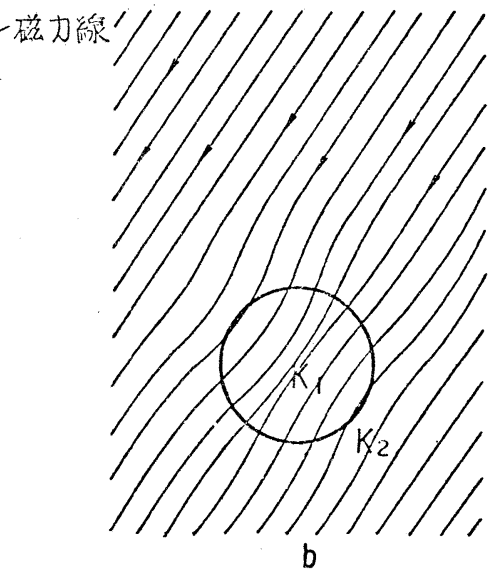

周团战带磁率加大き山

\section{$\left(K_{1}>K_{2}\right)$}

磁性体による磁力線の歪

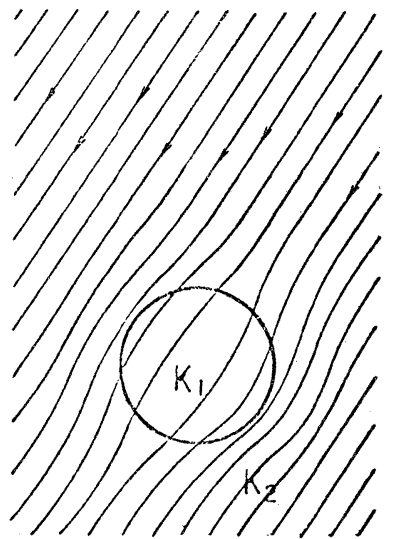

周埋より带磁率が小てい

$$
\left(K_{1}<K_{2}\right)
$$

磁力線は带磁率分布の変化によって歪を生ずる磁力線密度の変化が局地的磁気異常となる。

んでいる。特に磁鉄鉱は火成岩中の主要鉱物である。岩 石，地層の帯磁率はその内に含まれる磁鉄鉱によって支 配される。このように，ある大きさの帯磁率をもった岩 石は，上に述べた標準地球磁界のもとにおかれると磁界 の強さに比例して, 带磁 (磁化) † の状態となり, 地磁 気の局地的異常穵つくりだす。

地磁気の磁界は方向をもったベクトル量であるから地 磁気の 3 要素 (全磁力の強さ, 伏角, 偏角) によってこ れをあらわすことができる。空中磁気探査の場合，この 内, 地磁気の全磁力值分布を測定し, 等磁力線図（全磁 力図）にとりまとめるけ†。

\section{3. 解 䣋}

等磁力線図にあらわれる局地的地磁気分布の異常は, すべて調査地域内およびその周辺の地表あるいは地下に

†† $\vec{H}$ を地球標準磁界, $\vec{I}_{i}$ を誘導磁化とすれば $\vec{I}_{i}=$ $k \cdot \vec{H}$ となる。ここで $k$ は帯磁率である。局地的 磁気異常の原因となる磁化 $\vec{I}$ は上記の誘導磁化 $\overrightarrow{I_{i}}$ と残留磁化 $\vec{I}_{r}$ との和である。 $\vec{I}=\vec{I}_{i}+\vec{I}_{r}$ 但し, 一般には $\vec{I}_{r}$ は $\vec{I}_{i}$ に較べ非常に小さいととと $\vec{I}_{r}$ が大きいことは非常に少ないため，ほとえどの場 合 $\vec{I} \fallingdotseq \vec{I}_{i}$ とおくことができる。

††実際に測定される全磁力は, 地舀磁気の全磁力と 局地異常の全磁力とのベクトル和の絶対值をはか っている。しかし，局地異常の大きさは標準地球 磁界に較べ遙かに小さい為, 全磁力測定值からそ の地点の標準全磁力をさしひいたものを，局地的 全磁力異常として近似的にあつかうことができ る。

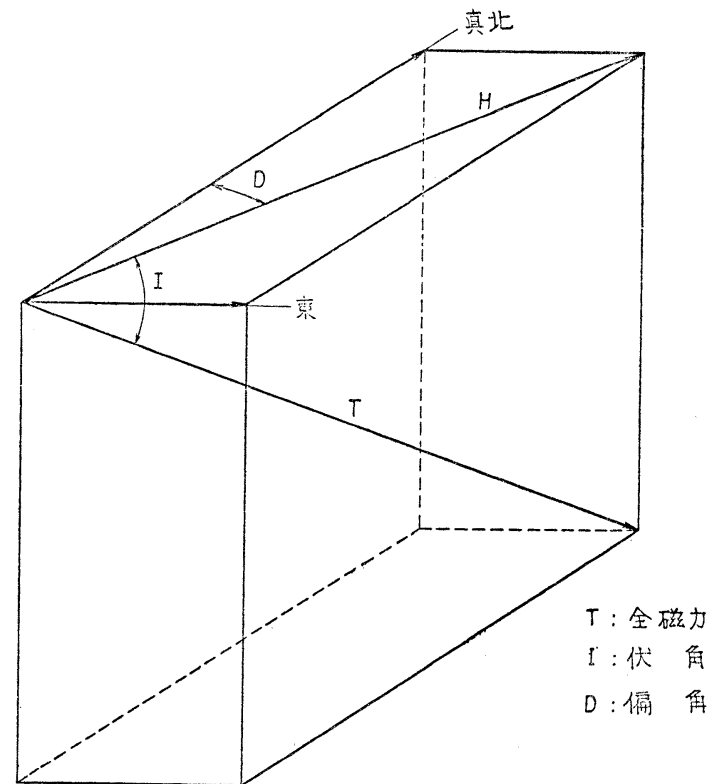

図 3 地磁気の 3 要素

存在する地層あるいは岩体によってひき起されている†。

全磁力測定值分布から，その地域の標準全磁力分 布をさしひいた結果得られる局地的全磁力異常 は，地表あるい地下に存在する磁性体によって ひき起されたものである。この局地的磁気 異常 $\Delta T$ は原因となる磁性体の形態 $f(v, r)$, 带磁率 $k$ および標準全磁力 $T_{0}$ によって決まり，近似的 には $\Delta T \fallingdotseq k \cdot T_{0} \cdot f(v, r)$ と表わすことができる。 ここで $f(v, r)$ 注性体の形状によるフォクタ一 $(v)$ と測定点と磁性体の距離 $(r)$ 飞関する関数と なる。例えば球状の磁性体がある場合， $v$ は体積 に相当し,$\Delta T \propto k \cdot T_{0} / r^{3}$ と表わされる。 
従って，逆に全磁力分布の形状から，磁気異常の原因と なっている地層（あるいは地層の集合体）あるいは岩体 の形態, 深さ，帯磁率它求めることができる。ここで求 めた帯磁率の大きさから，地層あるいは岩体を構成して いる岩石の種類を推定していくことが可能になり，地下

i）等磁力線（コンター）が円形に閉じているか，開いているか，あるいはコンターの歪として現われるか。

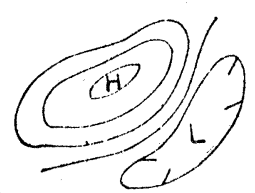

(閉じた)

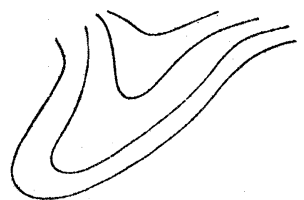

(開いた)

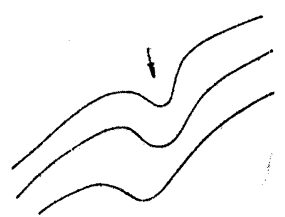

(コンターの歪)

ii）等磁力線間隔がこみあっているか，まばらであるか，すなわち等磁力線の公配が急であるか，緩いか。

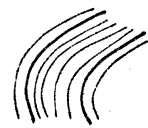

(勾配が急)

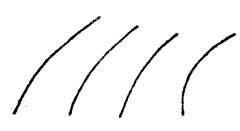

(勾配が緩い)

iii）円形に閉じを等磁力線, 開いた等磁力線あるいは等磁力線の歪が広い地域を覆っているか, 狭い地域を覆って いるか。

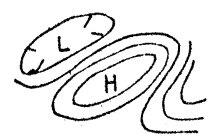

(㹟い)

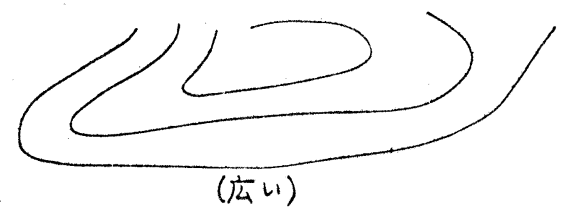

iv）等磁力線の流れる方向はどの方向か。

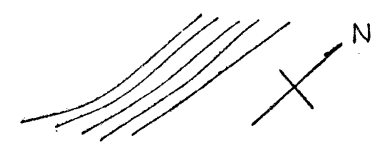

(南北に流水る)

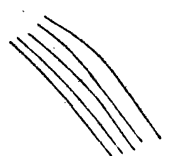

(相西に流水る)

v）i）にあげたような等磁力線の特徴がある方向に連続して追跡できるか，あるいは孤立した特徴であるか。

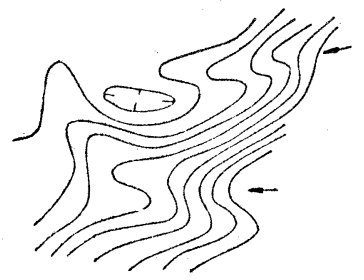

(歪が垖跡できる)

これら i） v）の磁気分布図上に一般に見られる特徵 について，预秥よそ次のように地下構造を考光ることが できる。

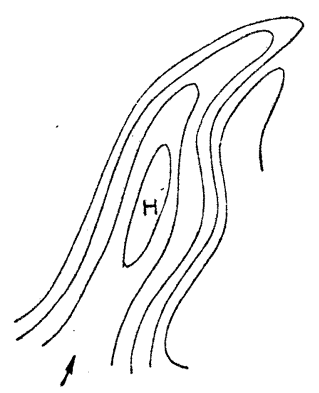

(磁気罢常がー方向にのびる)

i ) 円形に閉じた等磁力線があらわれる場合, 周囲の 岩石に較べ帯磁率の大きい火成岩体が存在する（貫 大火成岩体等)。 
ii）等磁力線の勾配が急である場合は，その付近に地 質あるいは岩体の境界がある。また浅いか，相接す る岩石の带磁率差が著しい(火成岩と堆積岩等)。

iii）閉じた，あるいは開いた等磁力線によって形成さ れる磁気異常が広い地域を覆っている場合は, 潜在 する構造は深いか，規模が大きい。

iv）等磁力線の流れる方向, あるいは等磁力線の歪が 連続する方向は，おおよそ境界，岩脈等の走向を示 している。

v）ある方向に連続して磁気異常が追跡できる場合 は，その下に断層，破砕带，岩脈等の存在を予想し 得る。

以上のように等磁力線図より，定性的におおよその地 下構造を推定することができる。一般には玄武岩，安山 岩等の火成岩は带磁率も大きく, 顕著な磁気異常となっ てあらわれ, 比較的小規模な岩脈, 岩床等の検出も困難 でない。凝灰岩，火山砕屑岩層などは中程度の磁気異常 をしめす。一方，頁岩，砂岩等の堆積岩層は低磁気異常 となって現われる場合が多い。また，断層，破砕带は低 磁気異常带となって現われたり，磁気異常を両断あるい は磁気異常内に歪带として現われることが多い。過去に 熱水蒸気，あるいは断層，破砕により変質をうけ，磁性 足失なってしまった岩石，地層は低磁気異常となってあ らわれる。

実際には，地下において岩体，地層はさまざまな形態 をとるため，次の段階では，理論的に計算される種々の 地下構造モデルと実際に得られた等磁力線図あるいは磁 力断面との定量的比較照合社行ない，潜在する構造の 形態および帯磁率を求めていく必要がある。これらの定 性的 - 定量的解釈は他の地球物理学的情報, 地質学的情 報と共に検討され，最終的構造が決定される。

\section{4. 実例}

\section{例 1}

第 3 図は青函トンネル通過地域の地下構造調查に応用 した例である。図に示した地域は訓縫層（訓縫層第 1 層 〜第 4 層: グリーン・タフ）により構成されており, 既 にトンネル予定線通過レベルの上下に, それぞれ作業坑， 先進導坑が掘り進んでいる。想定地質断面に記入されて いる玄武岩体（記号 $\mathrm{Ba}$ ) は先進導坑，作業坑に出現し， 確認されたものである。これらの岩体は等磁力線図にあ らわれる磁気異常に一致しており, 各々の磁気異常を解

†地下構造モデルとして岩脈，岩床，断層，岩株そ の他，多数のものが用いられ，それらを単独ある いは組合せて使用していく。
析した結果得られた玄武岩体の形態は推定地下構造に示 すとおりである。このうちトンネル予定線 $35 \mathrm{~km}$ 付近 に出現する玄武岩は比較的規模が大きく，一部先進導坑 に出現しているが，さらに深くなると容積を増すものと 推定される。この立武岩は一体の貫入岩体というより複 数個の岩脈によって構成されている可能性がある。

\section{例 2}

第 4 図はやはり青函トンネル通過地域の一断面であ る。この地域は黒松内層（黑松内層第 1 層〜第 5 層: 堆 積岩層）により構成されている。地質調査の結果による と，この地域の地表および地表付近には火成岩体の存在 は予想されていない。空中磁気探査の結果によると，地 表付近に火成岩の存在が予想され，岩脈が存在する可能 性もある。第 5 図に示した磁気断面図は，顕著な磁気異 常が観測される尾根を横断して, 地上磁気測定を行なっ た結果である。この地上磁気測定の結果によっても，地 表付近に火成岩体が存在していることは確実なととがわ かる。

\section{例 3}

第 6 図は地層が熱水变質を受けている地域の例であ る。熱水変質をうけている地域は，構成岩石が磁性を失 ない，全磁力断面には低磁気異常地域となってあらわれ ている。また，乙の低磁気異常地域の中にも，比較的規 模の小さい高磁気異常地域があらわれ，この高磁気異常 地域は熱水変質を受けていない地域と考えられる。また トンネル掘削等で問題になる比較的新しい火成岩で地層 が構成され，熱の予想される地域では度々，非常に強い 残留磁気異常が観測され，熱に関する情報を提供する。

\section{5. 結 論}

現在まで実行された応用例から，次にあげることが結 論づけられる。

1）火成岩の種類（空中磁気探査によって求められた見 掛け带磁率から推定する), 形態, 寸なわち，かくさ れた火成岩の分布, 配列, 深さ, 傾斜を推定すること が可能である。

2）潜在する断層，破砕带の発見が可能である。この場 合, 断層, 破砕带は磁性体の形状をかえたり, 両断し たりする。また断層, 破砕带の部分が磁性を失なった かたちで磁気分布図上にあらわれることが多い。

3）地熱, 鉱化作用により岩石, 地層が変質していると ころを知ることが可能である。

4）調查測線は密にとり，調査航空機は低空飛行をする 必要がある。これは比較的小規模な岩脈, 断層, 破砕 帯等を正確に検出する為であり，密な調查測線，低空飛 


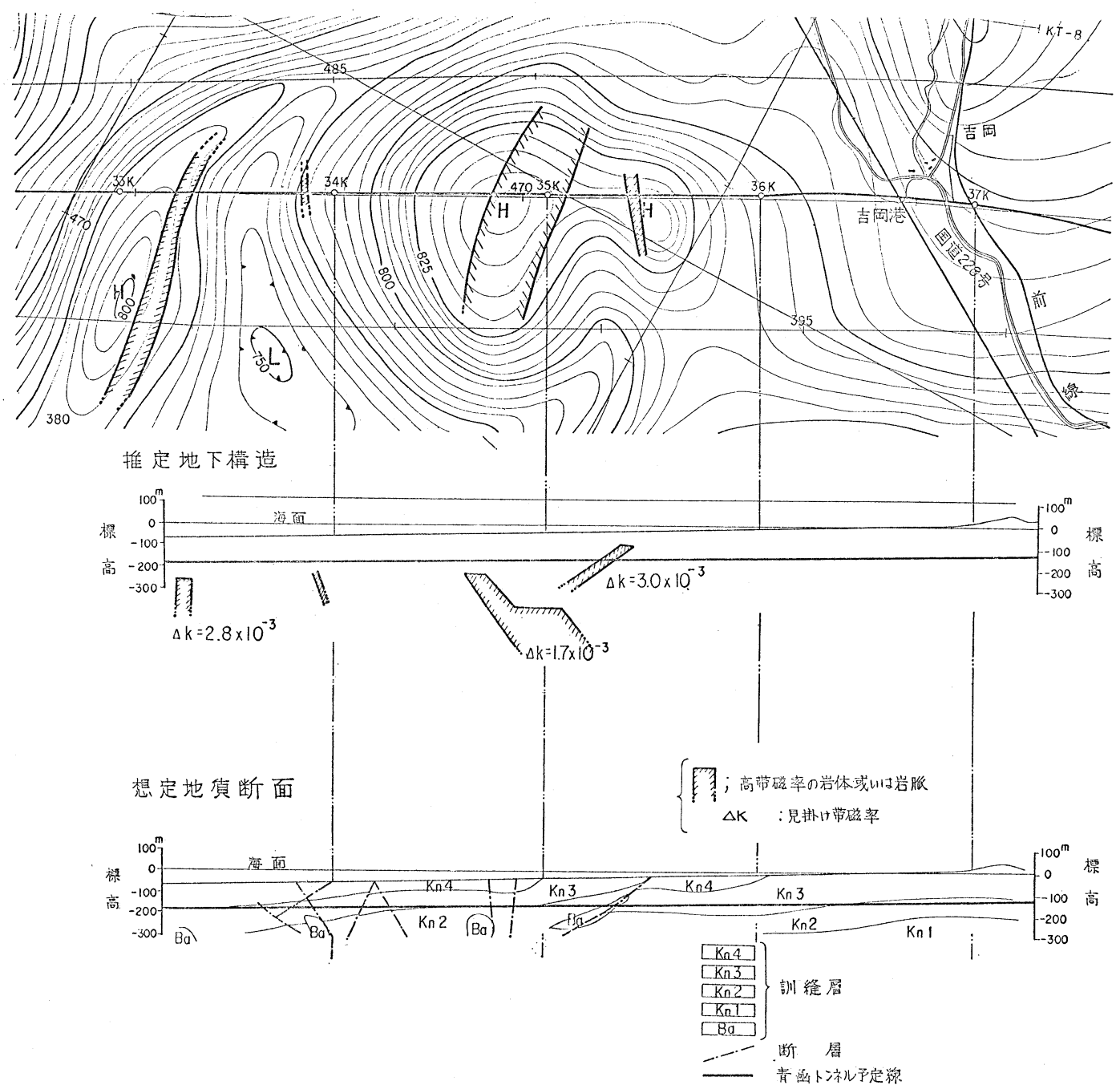

第 3 図

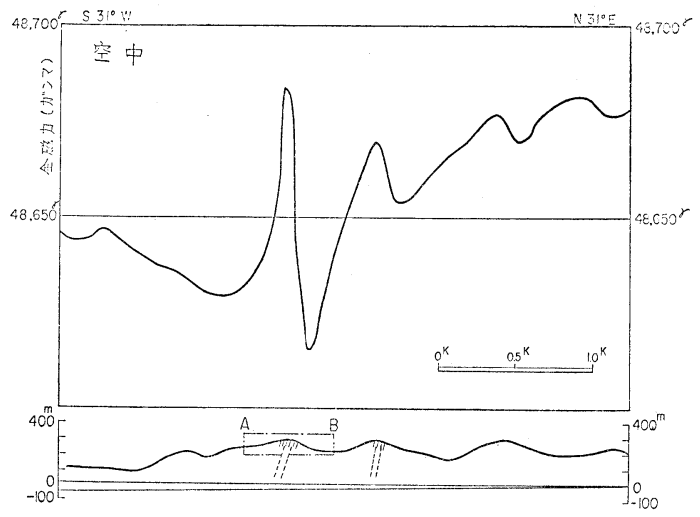

第 4 図

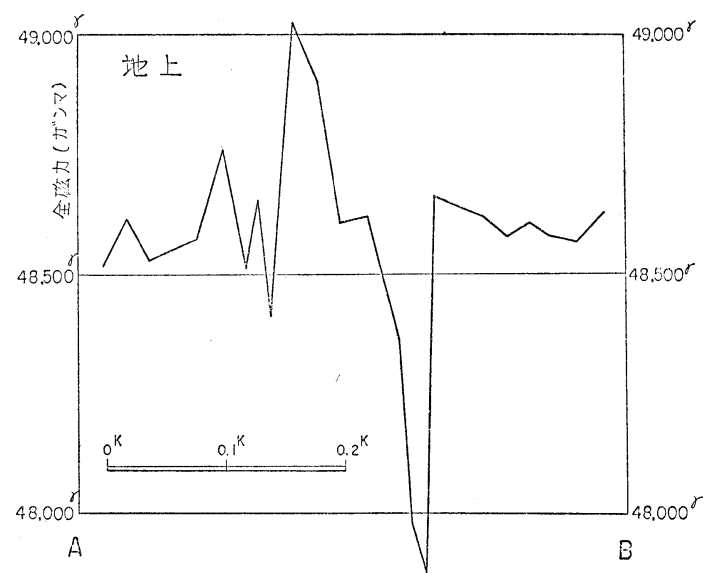

第 5 図 

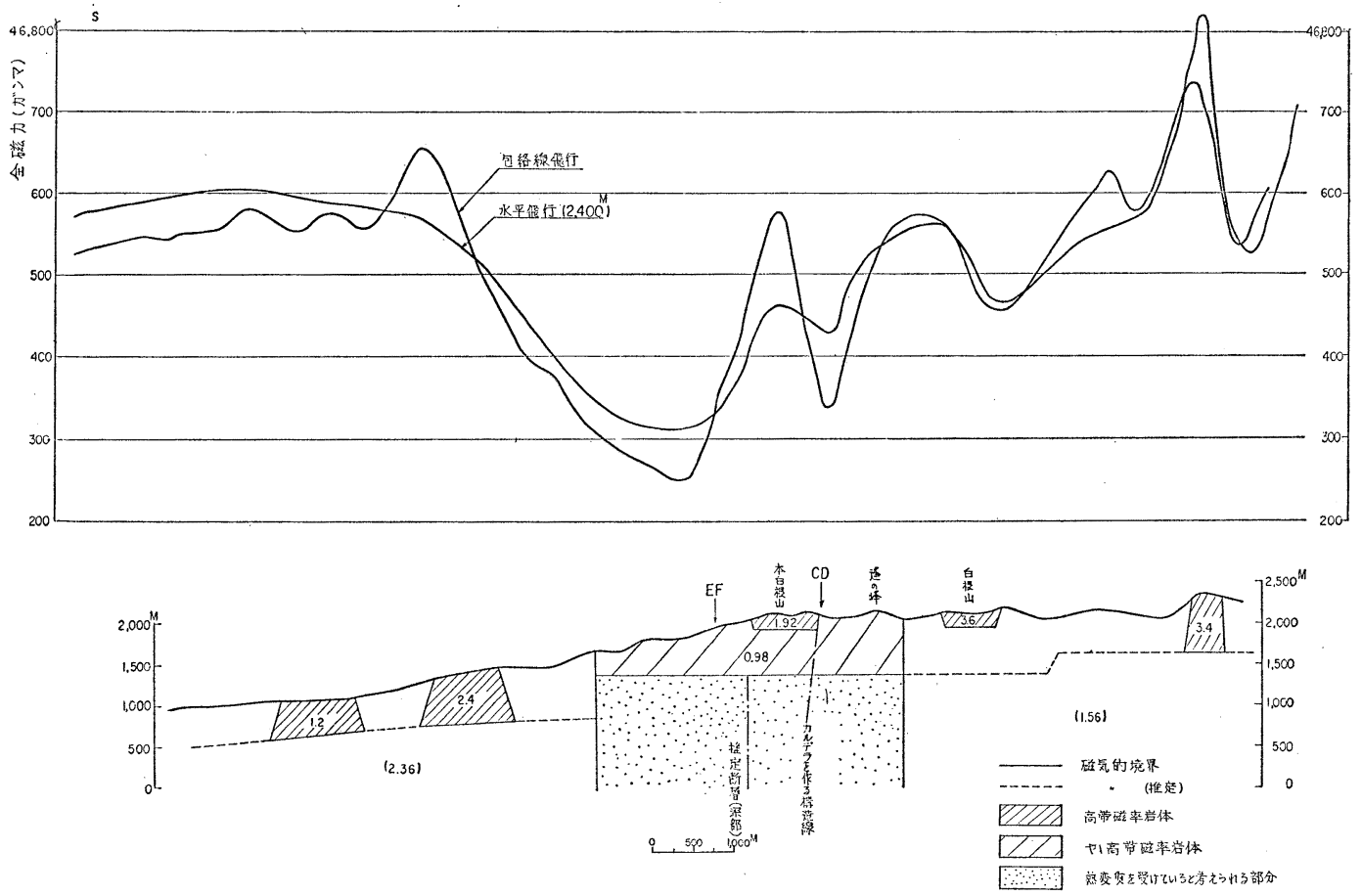

第 6 図

行を抜きにしては，空中磁気探查の土木への応用は成 り立たないであろう。具体的には, 調查主測線は $250 \mathrm{~m}$ 間隔以下，測定高度は平均対地高度 $200 \mathrm{~m}$ 以 下に設計する必要がある。特に飛行高度については， さらに低くとり，場合にとっては地形沿いに飛ぶ必要 も生ずるであるう。従って, 調査に使用する航空機は, 低空飛行，トップラー・レーダーで測線に正確に誘導
される小まわりの可能な小型機に限定される。

5）隧道等の調查の場合には, 計画路線の両側に, それ ぞれ 4 5 km 幅で調査範囲を設ける必要がある。

6）以上にあげた条件究した場合，25,000分の 1 程度 の地下構造平面図および，地下構造断面図を作成する ことが可能である。 